\title{
Students' Needs Analysis in an EFL Program for University Professors
}

\section{Análisis de las necesidades de los estudiantes de un programa de inglés para profesores universitarios*}

\author{
Paula Andrea Bedoya \\ pandrea.bedoya@udea.edu.co
}

Luz María Valencia lmaria.valencia@udea.edu.co

Juan Carlos Montoya

juan.montoyal@udea.edu.co

Universidad de Antioquia, Medellín, Colombia

This study sets out to investigate professors' needs from an English as a foreign language program in a public university regarding demands, interests, and lacks based on the methodology of needs analysis. Data collected through a survey, focus groups, and individual interviews showed that professors need to meet the institutional language policy for contractual and academic reasons. Additionally, data revealed their desire to learn English to communicate in both academic and non-academic settings. Moreover, the lack of time and effective learning strategies were reported as comprising the main constraints for learning. Finally, the authors present the strengths and weaknesses of the program as well as the participants' suggestions for curriculum restructuring.

Key words: English as a foreign language, language policies, learning strategies, needs analysis.

Este estudio se enfoca en investigar las necesidades de profesores de una universidad pública al aprender en un programa de inglés como lengua extranjera en términos de demandas, intereses y caren-

* Received: January 15, 2015. Accepted: July 11, 2015.

How to cite this article (APA $6^{\text {th }}$ ed.):

Bedoya, P. A., Valencia, L. M., \& Montoya, J. C. (2015). Students' needs analysis in an EFL program for university professors. HOW, 22(2), 11-36.

This article is licensed under a Creative Commons Attribution-NonCommercial-NoDerivatives 4.0 International License. License Deed can be consulted at http://creativecommons.org/licenses/by-nc-nd/4.0/. 
cias según la metodología del análisis de necesidades. La información recolectada de una encuesta, grupos focales y entrevistas mostró la necesidad de cumplir con la política lingüística institucional por razones académicas y contractuales. Además, los datos revelaron el deseo de aprender inglés para comunicarse en situaciones cotidianas y académicas. Asimismo, la falta de tiempo y de estrategias de aprendizaje efectivas se reportaron como los principales obstáculos para aprender. Finalmente, se presentan las fortalezas y debilidades del programa y las sugerencias dadas por los participantes para la restructuración curricular.

Palabras clave: análisis de necesidades, estrategias de aprendizaje, inglés como lengua extranjera, políticas lingüísticas.

\section{Introduction}

Internationalization has impacted higher education dynamics. Now universities have to go along with the political and economic tendencies the global world imposes. To be part of such reality, universities have to promote research and scientific community building among their professors (Asociación Colombiana de Universidades, 2003; Ministerio de Educación Nacional, 2009). Within this scenario, English has become the language of science and technology, and universities now have to require their professors to be competent in that language (Tollefson, 2007) for participating in such trends.

To respond to internationalization in higher education, the university participating in this study provides its professors with training through an English program. This program pursues the achievement of professional development goals and the attainment of "competences in a foreign language renowned in the scientific community of the working field that improves the quality of graduate programs for being an academic communication and scientific production tool"1 (Consejo Académico de la Universidad de Antioquia, 2008).

Although the professors recognize the strengths of the program, some have suggested implementing some improvements (as we shall see later on). Besides, the English teachers have also expressed the compelling need to revise the curriculum since the current one does not fully meet the professors' academic needs.

Therefore, this research project-based on the methodology of needs analysis — aims at expanding, clarifying, and systematizing the available information of what the university professors need concerning English learning in order to contribute with enlightening recommendations for the program's curricular restructuring.

\footnotetext{
1 Translated from Spanish.
} 


\section{Theoretical Framework}

This section will review some concepts on language policies and factors that motivate and influence foreign language learning processes.

\section{Language Policies}

According to critical perspectives on language policies (Hornberger, 2006), foreign language learning may be determined by regulations that respond to two orientations: Top-down and bottom-up (Shohamy, 2006). The first one is formulated by external agents who decide what language should be adopted, used, taught, learned, and evaluated (Canagarajah, 2006a). The second one explores the social, cultural, and political reality of the local community attempting to account for its needs and interests (Baker, 2006; Phillipson, 2006).

According to Spolsky (2004), "Language-management efforts may go beyond or contradict the set of beliefs and values that underlie a community's use of a language and the actual practice of language use" (p. 14); as a result,

the real language policy of a community is more likely to be found in its practices than its management, unless the management is consistent with the language practices and beliefs and with the other contextual forces that are in play. (p. 222)

When management disregards the community's real language uses, control over people's language practices becomes an illusion (Shohamy, 2006). Even if the policy is explicitly stated, as Shohamy (2006) claims, the language behavior may not represent the policy or contradict it. Furthermore, Shohamy argues that the community will "want to create their own language agenda" (p. 51).

Consequently, an English as a foreign language (EFL) curriculum proposal based on a bottom-up policy requires recognizing the reasons that lead individuals to learn it and understand the internal and external factors that influence its learning process.

\section{Factors Motivating Professors to Learn a Foreign Language}

Some of the reasons to study English relate to the desire for professional and personal growth, communicating with people from foreign cultures, and traveling to other countries. However, in Colombia, English is taught and learned rather to respond to academic and governmental demands. National language policies such as Law 115, 1994; the National Program of English: Colombia Very Well, Vision Colombia 2019 (Ministerio de Educación Nacional, 2006, 2014); and international certification English exams such as IELTS, TOEFL, TOEIC, influence the reasons and motivation to learn English. They restrict or allow access to graduate programs, scholarships, internships, and job opportunities. Plus, along with the 
signing of trade agreements that have taken place, the government has promoted a discourse where English is needed to respond to the world's new dynamic.

Furthermore, motivation plays an important role in the successful learning of a foreign language (Gardner, 1985; Kormos \& Csizér, 2008) because it explains a person's reasons to invest time and effort on learning. Moreover, the expected outcomes make the learning process more rewarding (Ryan \& Deci, 2000), especially in Colombia where English learning determines the possibilities of traveling, studying, working, and being part of an international society (Wu, Yen, \& Marek, 2011).

Other determinant elements in motivation include the students' systems of objectives, attitudes, and beliefs. A new objective emerges for professionals in the 21 st century: to be part of a cosmopolitan community and take a stance regarding academic and labor relationships with intercultural peers. English is not part of a specific culture anymore (Canagarajah \& Wurr, 2011), but it is regarded as a lingua franca that serves the constitution of a global community (Canagarajah, 2006b).

Therefore, becoming part of a cosmopolitan community is not merely instrumental and it is inaccurate to assume that it advocates only for what some authors (Gremmo \& Riley, 1995; Schmidt, Boraie, \& Kassagby, 1996) distinguish as extrinsic motivation. Plus, language policies foster collective imageries around the benefits of learning English that makes it difficult to separate extrinsic from intrinsic motivation. For instance, being part of the international scientific community is considered both desirable and satisfactory (Lamb, 2004).

\section{Factors Influencing Professors' Foreign Language Learning}

Some factors related to teaching, methodology, and learning context are called pedagogical variables (Espí \& Azurmendi, 1996). Gardner (1985) identifies two more factors: individual variables, which further include learning styles and learning strategies; and psycho-social variables which encompass social identity, attitudes towards the foreign language, and socio-demographic aspects such as age, gender, and socio-economic level. In addition, learning styles as an individual variable fall into three categories (Keefe, 1991; Alonso, Gallego, \& Honey, 1994): perceptual modality, information processing, and personality patterns. Finally, learning strategies as defined by Ghani (2003) are procedures used by the learners to make their language learning successful. Rubin (1987) defined them as behaviors, steps, and techniques applied by learners to facilitate learning. They may include focusing on selected aspects of new information, analyzing and monitoring information, organizing and elaborating on new information during the encoding process, and evaluating learning (O’Malley \& Chamot, 1990). 


\section{Context}

The English Training Program was created over 20 years ago as a verbal agreement and no record is available that accounts for its origin. Its main objective was to teach English to professors of the university in order for them to be able to face academic challenges presented by higher education. The current language policy strengthens the program (Consejo Académico de la Universidad de Antioquia, 2008, 2012). Both agreements regulate the certification in a foreign language for undergraduate and graduate professors. Regarding the studying population, many professors are graduate students or are involved in research. Ninety percent of them consists of adjunct professors, while the remaining $10 \%$ are faculty members. In addition, both of them arrived with very low levels of English.

That is why a lot of professors studying in graduate programs often take advantage of the courses to meet the requirement of English proficiency.

The program serves eight levels for free, 68 hours each, for a total of 544 hours of instruction with 830 professors participating in 2013. This amount of hours of instruction would correspond to B2 according to the Common European Framework of Reference (Council of Europe, 2001). There are also some complementary courses on listening skills, conversation, reading comprehension, academic writing, and preparation for international language tests.

\section{Method}

This research is based on the needs analysis theory from a learning-centered approach (Hutchinson \& Waters, 1987). Needs analysis is the process of identifying the reasons why professors require and need to learn a foreign language (Richards, Platt, \& Platt, 1992). The purpose of this research was to gather objective and useful data that help to evaluate an EFL curriculum. This study aims to consider both the professors and the context in which they learn.

Hutchinson and Waters' (1987) approach focuses on three types of requirements: demands, interests, and lacks. The first type focuses on identifying the environmental needs regarding foreign language learning. Such requirements are called "objective needs" (Richterich, 1985). They come from professors' educational backgrounds, their cultural and social conditions, their proficiency language levels, and their purposes to learn a language.

The second requirements are called "subjective needs." These include professors' interests and likes, considering what they want to learn and how. These needs are frequently associated with psychological and cognitive learning factors. Finally, there are requirements named shortcomings. These are linked to the professors' background knowledge and the 
possible limitations of the teaching-learning context that could determine the fulfillment of objectives. In conclusion, this study focused on both identifying the professors' needs when learning and providing some pedagogical recommendations to enlighten a curriculum reform.

\section{Data Collection Instruments}

Survey. A virtual survey was answered by 120 professors who had worked at the university for one year at a minimum. The purpose was to identify the professors' interests concerning class activities, topics, methodology, learning habits, and their previous English training (see Appendix 1).

Interviews. Five of 28 English teachers (ET) working in the program more than four years were interviewed (see Appendix 2). This information helped to identify to what extent the contents and methodology fulfilled the professors' learning needs. Two previous coordinators (C1 and C2) (see Appendix 3) and the Vicerrector de Docencia (VD) also provided information about the university demands regarding foreign languages (see Appendix 4).

Focus groups. Eleven focus groups (FG) were organized, each with about six participants who had replied to the virtual survey previously. The purpose was to clarify and obtain more detailed information on the answers they sent. All evidence was translated from Spanish.

\section{Data Analysis}

All the data were triangulated using both qualitative and quantitative components of content analysis (Krippendorff, 2004). First, the themes emerged from interviews and focus groups; second, the number or percentage of respondents was quantified from the interview and survey. The information was classified and analyzed through Nvivo10. The following categories were previously taken from the needs analysis methodology: Demands, Professors' Interests, and Professors' Shortcomings. Other categories such as Program Strengths, Program Weaknesses, and Suggestions emerged from data.

\section{Findings}

The following findings will be presented in three sections. The first is about the demands the professors have to meet concerning English proficiency as well as their interests and shortcomings when learning. The second illustrates the strengths and weaknesses of the program. And the third presents participants' suggestions. 


\section{Demands}

Regarding demands two types of concerns were found. The first concerns local and international educational dynamics. The second refers to the university language policy which regulates hiring and postgraduate registration processes.

Local and international educational dynamics. In an interview with the VD, the need for English learning to be competitive in university education became evident.

What is happening? Other universities are already ahead of us. They have [English proficiency] requirements to admit professors to some programs. Many courses are being taught in English now. So that is a disadvantage we must recognize and try to compensate it since the academic world is ruled by the English language.

The participants often expressed feeling pressured to publish their research articles in English and engage in international academic and cultural exchanges. One student summed it up as follows:

The University is inserted in an internationalization process. It means that all of us, in all areas, are included. It is from here the permanent request of writing our research papers in English and participating in international events either as assistants or as speakers. I think that having [English] communication skills to take part of those exchanges is necessary. (FG5)

Concerns regarding the language policy and the English competence certification. According to the language policy, the candidates to study in a graduate program or to apply for a position as full-time professors must certify their language level proficiency. The abilities required depend on whether candidates seek a specialization, a master degree, or a doctorate. As the VD states: "Especially on the subject of English, [we want] it to be used in their daily activities in teaching, research and external services." Nevertheless, the language policy represents a common concern for professors and administrators since an unacceptable English proficiency level limits access to full-time positions and graduate programs. C1 considers,

I have never agreed [to the language policy]. It seems unfair to me that having a language certification is more important and goes beyond that their professional credentials and capabilities. For example in [The Faculty of] Medicine some excellent professors were left out of the hiring process just because they had failed in their English examination test. Then I say, well, we have to reformulate the [language] policy. (Interview)

\section{Professors' Interests}

When the professors were asked about their interests, they focused on the following topics: preferences in class, study habits, opinions on English learning, and teaching undergraduate courses in English. 
Preferences in the English class. The professors commented on the modality of instruction, in-class activities, topics, Information and Communication Technologies (ICT) and the skills they prefer to develop the most. Concerning the modality of instruction, they showed preference for face to face instruction rather than virtual. Many affirmed that ICT may be an option to enhance independent work, but they must not replace in-person classes which allow interaction, as one of the professors expressed: "I need a teacher who listens and answers me, someone close to me" (FG7). In fact, this opinion as others found in the data evidences that the presence of the teacher is still necessary for them to learn.

Referring to in-class activities, professors feel more engaged in pair and group activities rather than individual work. They also prefer oral tasks such as oral presentations, debates, and role-plays. According to the virtual survey $91 \%$ of the professors like grammar since they believed it necessary to talk and write accurately.

Concerning the preferred topics to study, it was found that culture, daily news, social issues, and personal experiences are among their favorites. In the survey $47 \%$ showed interest in learning English for performing well in daily conversations. Besides, $41 \%$ reported to be interested in cultural topics, as this excerpt evidences: "I think it is one of the richest things of this program, we can learn about many topics" (FG reading comprehension). Although 35\% agreed on learning English for academic purposes, social and cultural topics were placed as the most relevant and interesting topics.

Regarding the use of ICT in class, professors and English teachers recognized that technological tools favor teaching and learning processes and confirmed that the implementation of videos and other digital texts enrich classes. A teacher argued: "ICT are a great support for working in class, they expand our possibilities" (ET2, Interview).

Concerning language skills, professors want mainly to develop the oral and listening ones, since they wish to participate fluently in conversations. This is illustrated in the following excerpt: "It is frustrating not to be able to express ideas as we want" (FG5).

Study habits. Data showed that activities such as reading news and research articles, watching movies and TV programs, and listening to music are the ones most practiced by the professors. One expressed: "While watching movies or listening to music, I have fun and learn" (FG reading comprehension). Grammar exercises are also included in the activities they do independently. One student stated: "I like to do grammar exercises online" (FG6). In contrast, chatting was not a study habit.

Related to the use of technological resources and materials for learning, the most mentioned were TV series, movies with caption, books, magazines and videos, and music on the Internet. Some professors use language platforms such as Live Mocha, LinkedIn, Rosetta Stone, and La Mansion Inglés. However, the majority manifested neither using social networks 
nor electronic devices to study. For example, $35 \%$ stated using multimedia players, $31 \%$ study on language platforms, and only $28 \%$ assured they use social networks for practicing. Data revealed that professors rarely use applications and electronic devices because of the lack of time, motivation, and the lack of skills to handle them, as this excerpt illustrates: "Despite the existence of wikis and other resources to study, I think they are not familiar to us" (FG6). Another student stated "The Iphone [iPhone] and social networks are a culture, and I do not feel part of it" (FG writing).

With respect to time, many professors pointed out not to have enough to study as they wanted. They even confessed they should study more, as claimed by a student: "The effort one makes is not big, in my case; I should dedicate more time to study" (FG3). According to the survey, 33\% of them study between three and four hours a week, $29 \%$ spend one or two hours studying and only 13\% study five or more hours weekly. In both the survey and the focus group, the professors recognized their lack of discipline.

When the professors were asked if they talked to other English speakers to solve doubts or to practice, most of them affirmed they have few opportunities to practice with others. The following comment shows this: "Although I have some friends abroad, I do not practice with them because they are not patient" (FG4). Also, data showed that only $8 \%$ talk to advanced learners or native speakers. To sum up, the professors have few chances to develop their oral skills by talking to others.

Opinions on English learning. Thirty-eight percent of the professors agree on using Spanish in the classroom. They consider it appropriate to use their mother language for understanding. About the way professors face language learning constraints, they affirmed that they feel discouraged when they experience academic failure or do not see their progress. They asserted in both the survey and the focus group that learning English implies effort and dedication and that this process relies mostly on them. In the focus group a student stated: "learning English is a personal commitment, it involves work and attitude" (FG3).

Teaching in English. In relation to the use of English in their undergraduate courses, 83\% answered to be interested in teaching their subjects in English. They do not do it because neither their students nor they have the language skills and confidence to interact properly. Although some undergraduate students can read, most of them cannot understand spoken English. However, some professors use papers in English because they are aware of the need of exposing their students to technical texts in their original language.

\section{Professors' Shortcomings}

In this section, the needs and barriers professors find along their English training are grouped together. The aim was to understand the aspects that prevent the professors' 
desirable performance while carrying out their academic activities and also the reasons to leave or fail the courses. Most of the concerns are related to lack of time, work overload, and learning constraints.

Lack of time and work overload. Thirty-two professors showed how the time factor and the work overload have been the biggest barriers affecting their performance and continuity in the program. As a matter of fact, just $10.38 \%$ of the professors hold full time contracts with the institution, so most of the rest are obligated to look for other part-time jobs to complement their salaries.

In addition, the university establishes different calendars in its academic units given the frequent strikes. When a faculty, school, or institute begins a new semester, its schedule often gets crossed with the one established in the program, so the professors are forced to quit. The lack of time keeps them in a constant state of tiredness that often pushes them to relegate English learning to the last of their priorities. One student claimed: "You could mention three main problems: Time, the type of labor agreements, and the diversity of calendars" (FG2).

Preparation for proficiency exams. Some professors manifested that the program helps them to prepare for proficiency tests. However, others expressed that the courses do not help them prepare fast enough to pass the proficiency test for the faculty selection process. Moreover, some professors think the courses do not foster all of the skills evaluated in such tests, especially listening and writing skills. A student expressed: "Although we sometimes write in class, I do not feel confident when writing. I need more practice" (FG5). Some professors even claimed that they have to hire tutors to prepare well and on time for the tests. As claimed by one student: "For passing the TOEFL, I had to take private classes, the hours of instruction were not enough in the program" (FG6). From this evidence we can infer that the professors need to be prepared not only for performing in English but also for passing proficiency tests, tests for job openings and graduate studies.

Professors learning difficulties. This project does not explore deeply the origin and causes of the professors' learning apprehension. However, 15 professors mentioned lack of discipline and interest to study autonomously and fear of looking ridiculous. "It's a silly thing. I feel embarrassed to speak English. I feel shy but I don't understand why. I say, I am just learning. That happens very often to me and to my classmates" (FG4).

\section{Program's Strengths and Weaknesses}

In this section, the findings related to the program's strengths and weaknesses and the more notable teachers' practices are described. Strengths and weaknesses are classified into five themes. The first one covers courses' time and schedule, and their suitability regarding language proficiency tests. The second one refers to the program's teachers and professional 
development opportunities. The third theme relates to the program's syllabus. The fourth one gathers the participants' opinions about classrooms and other resources.

Time and schedule. The courses' time and schedule are critical for professors. On the one hand, they regard it as a positive aspect that the program provides courses at extreme hours. On the other hand, some complained because the program does not satisfy their time constraints. "I quit two courses because I had to teach a course at the same hour" (FG6). Additionally, the VD asserted: "The program's academic term does not match the university calendars." Also, the teachers think that the different schedules affect professors' continuity and performance. One claimed: "It limits the professors' availability to attend classes and accomplish assignments because of their overbooked agendas" (ET1, Interview).

One of the coordinators stated: "Our professors do not usually have time to complete the courses. Many have to show proficiency without being prepared” (C2, Interview). Besides, the professors affirmed the courses are too slow, the amount of classes per week is insufficient, and finishing the upper levels takes too much time. A student expressed: "A course takes a semester and one needs faster training" (FG7).

English teachers, classes, and professional development. Professors expressed different opinions about the diversity of teaching strategies and activities used in class. Other aspects include commitment, flexibility, and evaluation criteria. For some professors the English teachers encourage them to use English and display a great variety of strategies and activities. This excerpt cites a case in point: "I think the classes are always interesting and enjoyable (FG6). Besides, some professors recognize the importance of having teachers who understand their complicated agendas affecting homework and attendance. A student claimed: "I sometimes skip classes because of my duties. If I did not have this support, I would never finish a course" (FG5).

About classes, some professors feel more confident speaking English and think the courses are very good. An example: "I have made progress. I am less shy now. I always participate in class" (FG6). Evidence proves professors feel motivated towards the courses because they open up spaces for sharing with colleagues. A teacher asserted: "One positive thing of the program is that it provides professors with a space to meet colleagues" (ET3, Interview).

Conversely, some professors in three focus groups expressed their disappointment regarding the level of demand and evaluation criteria. Some of them find that language and evaluation standards are too low. For instance, "some teachers are too flexible and do not keep high standards in their classes to avoid drop outs" (FG3).

Moreover, data indicated that $20 \%$ of the professors think their teachers lack rigor and commitment. The evaluation guidelines remain unclear and some teachers ignore what and 
how to evaluate. One teacher manifested: "Everyone teaches and evaluates in a different way. Although we know we have to follow the communicative approach, we do a mixture of things" (ET4, Interview). Also, one of the coordinators claimed: "Despite of [sic] the discourses about the communicative approach, some of the tasks they propose are not communicative" (C1, Interview).

In addition to these lacks, the program faces weaknesses in procedural guidelines and professional growth opportunities offered its teachers. Opportunities for professional development do not reach all of the teachers because they work at different universities and language centers, which leave little or no time to attend professional development workshops. A teacher expressed: "Although I know meetings and workshops are important, I cannot attend all of them because I have to work" (ET5, Interview).

Nevertheless, three of five teachers argued that meetings with the coordinator facilitate unifying some procedures and implementing some changes which have improved their courses. For example, they make decisions regarding evaluation as a group: "We have decided how to design the exams together" (ET1, Interview). In conclusion, the coordinators and teachers' comments revealed that professional development workshops are necessary to unify criteria.

Syllabus. Most of the professors and teachers expressed some positive views about the syllabus. A significant number of the professors enjoy complementary courses since they focus on developing specific skills. Three teachers affirmed the syllabus was excellent, balanced, and structured. However, both coordinators explained that there were no written documents defining contents or methodology for the professors' academic context. Instead, each course is based on specific chapters of a textbook. This declaration may provide insights on the lack of clear guidelines and evaluation criteria and indicates that the program documentation has been insufficient since the syllabus has been basically based on the contents of a textbook. Also, the other two teachers manifested in the interview that the contents of the textbook are not reliable and do not meet the professors' needs. This comment shows this: "Our professors need other kinds of readings and audios. The ones of the textbook are not practical enough for their academic context" (ET4, Interview).

Classrooms and resources. The lack of classrooms and teaching resources represents the main difficulty for the program. According to the survey, $90 \%$ of the professors complained about the poor conditions of classrooms and asked the administration to solve this problem. As claimed by one student: "I have felt demotivated due to the lack of ICT in classrooms" (FG1). The coordinators manifested that finding available classrooms has been the main challenge of the program. One of them stated: "This is the general complaint, not to have classrooms" (C1, Interview). Moreover, the teachers affirmed that this issue limits and 
sometimes thwarts their job. This excerpt illustrates this: "One needs resources for teaching English, for making our classes more appealing to professors" (ET3, Interview).

This happens because deans do not guarantee availability before all undergraduate classes are assigned leaving insufficient classrooms for the program. Concerning this, a coordinator argued: "We do not have enough support from the administrators" (C2, Interview).

Teacher practices. The data also showed that teachers use a great variety of activities. Their practices are sorted into three groups: teaching exercises, evaluation tasks, and homework assignments. According to the survey, some in-class activities include basic written exercises such as descriptions and summaries at the beginner's levels, and academic writing in the advanced ones. Other activities consist of oral presentations about the students' expertise and interests, memorization of dialogues, readings and debates about social and cultural topics. Some of instructors promote group work and try to select activities according to the group interests and needs as well.

When the teachers talked about evaluation, they affirmed using both formative and summative assessment. Besides a mid-term and final evaluation, they try a wide variety of assessment tasks during the follow-up such as role plays, oral presentations, quizzes, debates, dictations, written assignments, and transcriptions. The teachers also give feedback to professors and sometimes use rubrics. A teacher asserted in the interview: "I always use rubrics for assessing oral presentations and other tasks that imply discussion and argumentation" (ET3, Interview).

Apropos of assignments, all the teachers recommended textbook exercises and Internet resources as homework. They also asked professors to do transcriptions and watch documentaries and videos. In conclusion, teaching activities and evaluation range between communicative and traditional tasks.

\section{Suggestions for the Program}

With reference to the academic field, both coordinators and teachers suggested moving towards the development of academic skills. A teacher manifested: "Instead of following a textbook, we should design authentic tasks for professors" (ET5, Interview). Also, a coordinator expressed: "We could develop a syllabus including academic tasks to train professors to deal with academic tasks" (C1, Interview). Another suggestion made by them was to continue revising the evaluation procedures and providing teachers with training in that area. Although they recognize the program's efforts to provide professional development on evaluation, they asserted that more reflection is needed. This excerpt illustrates this: "The program must provide their teachers with professional development to foster reflection and negotiation in evaluation" (C1, Interview). 
Furthermore, a significant number of professors expressed that they would like to have a site or platform with a digital repository for learning material and a teacher online to solve doubts and facilitate conversation at different hours. Some professors manifested: "It would be great to have a tutor online to practice what we study in class" (FG4). Some of them expressed not succeeding when studying at home. Although many of them watch videos and listen to music, they feel they are not learning. One student claimed: "I try to study by myself, but I often forget what I learn. It would be good that the teacher shows us how to do it" (FG3). Many professors also added that although they have electronic devices they do not use them to study. This excerpt cites a case in point: "I know that we can learn languages through technology, but we do not know how" (FG7). Then, they suggested they be trained in their use.

As to administrative matters, all participants expressed the need of having better classrooms and suggested the program offer a flexible schedule and courses at alternative hours. For instance, some professors find it practical to recover skipped classes at a different hour. A student maintained: "It would be beneficial if we could attend another class of the same level at another hour" (FG8). Moreover, one common comment in the survey was: "The program should offer courses at different hours, not only at noon or 6 p.m."

Finally, there is a last repetitive suggestion made by the professors, the coordinators, and the Vice Rector. The university should give professors who have passed the selection process the opportunity to improve and certify their language proficiency within the trial period. Some professors asked for such consideration in order to accomplish the language requirement for job openings at the university. One student asserted: "Great professors have lost the opportunity to get a full-time position because they do not have the [English] proficiency level. It is not fair. They could study and show their progress within the trial period". (FG6). The VD also expressed his interest in this matter: "I think it could be possible that [in the program] our professors reach the level needed. This is one of the topics the administration is reflecting about in relation to language policies" (Interview). It would be necessary that the leading group in charge of designing the new language policy know of and consider this suggestion in order to include more voices.

\section{Discussion}

This study gives attention to professors' needs in terms of language demands, their interests and difficulties. Regarding these issues, language policy is discussed when addressing demands. On the topic of interests, pedagogical recommendations are offered to make the program more suitable for professors' preferences. Finally, some administrative considerations are developed to tackle organizational barriers. 


\section{Demands and Language Policies Implications}

In the case of this university, the language policy demands that professors be competent in English to join the international academic community and contribute to fostering university goodwill. Similar exigencies have been analyzed by Shohamy (2006) and Canagarajah (2006a) when claiming that language policies aim at gaining status, power, group identity and belonging.

In attempting international academic recognition, the university excludes those who cannot certify [English] language proficiency. For instance, participants expressed their concern as to how professors' goals are affected. Accessing academic and job opportunities are hampered since the regulations impose a proficiency level that professors cannot achieve. In this regard, the university overlooks professors' needs in acquiring EFL. This is what Shohamy (2006) calls the oppressive use of language policies. This oppression originates from the international pressure universities experience to respond to political and economic world trends (Usma, 2009). Moreover, Hughes (2008) highlights the reality that universities in the outer circle face exclusion since they are forced to certify English knowledge.

Universities must take into account the factual use of the language, the hours of instruction, and background knowledge when planning a foreign language policy. In this university, professors suffer discrimination as the policy prevents them from participating in academic dynamics. Concerning this issue, Hughes (2008) warns that language proficiency should be acquired "in the middle of instruction and not as part of the criterion for programs admission" (p. 126). Therefore, this university should focus on EFL instruction rather than impose certifying regulations.

\section{Interests and Pedagogical Recommendations}

The implementation of communicative tasks, study skills, alternative assessment, ICT for learning, and teaching and learning strategies must be revised to target professors' interests when learning. These five aspects are discussed as pedagogical recommendations.

Promoting the use of communicative tasks should be the basis of syllabus design. The data showed that teachers carry out a mixture of activities that are not always communicative. Also, there is ambiguity on evaluating with communicative purposes. By including task-based instruction in the curriculum, professors could develop language skills while performing a task, as Brandl (2008) claims, to wit: "Language use is the driving force for language development" (p. 7).

Besides adopting communicative tasks, the syllabus should include the enhancement of study skills promoted in the English for general academic purposes (EGAP) approach. Effective lecture listening comprehension, note-taking, writing in the appropriate academic 
register, and participation in discussion are some of them (Shim \& Sim, 2011). In this case, the program could include contents and strategies to prepare professors to complete tasks in a general academic setting. Moreover, working on this approach, professors will also develop skills for teaching their subjects in English, which they need according to the data. As Flowerdew and Peacock (2001) state: "EAP is the teaching of English with the specific aim of helping learners to study, conduct research or teach in that language" (p. 8).

Evaluation must be clearly defined in the curriculum. Alternative assessment could meet professors' needs since it promotes contextualized communicative tasks, interactive performance, and intrinsic motivation. Furthermore, alternative assessment is formative and continuous (Brown, 2001). Although data showed that teachers use qualitative assessment, these practices must be stated in the syllabus and promoted as a regular practice.

Another aspect to be included in the curriculum is the implementation of ICT for learning and teaching. A platform and online tutoring could motivate independent work. Thus, the program should continue promoting face to face courses and including ICT in both classroom and self-study activities.

Finally, teaching the professors learning strategies is also suggested for the curriculum. The data showed difficulties regarding self-study. Despite doing independent work, some professors feel they do not improve. Also, most of them want to use devices and applications for learning. Therefore, the program should promote the development of learning strategies using ICT. These pedagogical recommendations would help the program to target professors' interests and learning preferences. Hence, including professors' needs contribute to the construction of a democratic curriculum.

\section{Difficulties and Administrative Considerations}

The national education policies concerning widespread coverage have brought unforeseen negative consequences such as the lack of classrooms and equipment, and a decline in the quality of education. This university and the EFL program suffer these consequences as well. To solve these difficulties the administration's financial support is needed. Although the findings showed these lacks are clearly evident, the university has not taken actions to improve these conditions. This attitude perpetuates certification practices instead of promoting the development of language competence through instruction.

\section{Conclusions}

This study aimed at investigating what the professors of a public university need for learning in an EFL program in terms of demands, interests, and lacks based on the methodology of needs analysis. Results showed that many professors enroll in the program to 
meet the language policy for contractual and academic reasons. In this regard, this language policy has affected professors in two ways. First, in the haze of meeting requirements, many professors are motivated to certify rather than enjoy a formative process. Second, the policy does not contemplate professors' difficulties such as low language background and lack of time and learning strategies.

Since lack of time and study habits were the main difficulties for learning, the curriculum should include explicit teaching of strategies and ICT for learning (Siemens, 2006). Therefore, support from the administration to access resources required and train English teachers is needed.

Additionally, to include ICT and learning strategies in the curriculum, the program must prepare professors to perform in an international university. This agenda requires professors to communicate with academic peers in various situations. Therefore, the program must adopt EGAP for two reasons. One, this approach enhances study skills. Two, EGAP promotes language learning through communicative tasks.

Despite the pressure of internationalization, the institution must consider lessening the impact of this process. This study showed the need to discuss the language policy and recommend pedagogical and administrative actions. First, the university should consider bottom-up approaches to language policy to grant the academic community with opportunities to learn meaningfully. Plus, university programs must promote the development of study skills in their language courses to prepare learners to face academic and labor language demands. Finally, the authors highlighted the relevance of the administration in overcoming the difficulties found.

\section{References}

Alonso, C. M., Gallego, D. L., \& Honey, P. (1994). Los estilos de aprendiraje: procedimientos de diagnóstico y mejora [Learning styles: Improvement and diagnosis procedures]. Bilbao, ES: Ediciones Mensajero.

Asociación Colombiana de Universidades. (2003, October). Hacia una internacionalización de la universidad con sentido propio [Towards an internationalization of the university with identity]. CX Consejo Nacional de Rectores, Bogotá, Colombia. Retrieved from http:// secretariageneral.univalle.edu.co/consejo-academico/temasdediscusion/2003/Agenda $\% 20 \mathrm{~d}$ e\%20Pol\%EDticas.pdf.

Baker, C. (2006). Psycho-sociological analysis in language policy. In T. Ricento (Ed.), An introduction to language policy: Theory and method (pp. 210-228). Malden, MA: Blackwell Publishing.

Brandl, K. (2008). Communicative language teaching in action: Putting principles to work. Upper Saddle River, NJ: Pearson Education.

Brown, D. H. (2001). Teaching by principles: An interactive approach to language pedagogy. New York, NY: Longman. 
Canagarajah, A. S. (2006a). Ethnographic methods in language policy. In T. Ricento (Ed.), An introduction to language policy: Theory and method (pp. 153-179). Malden, MA: Blackwell Publishing.

Canagarajah, A. S. (2006b). The place of world Englishes in composition: Pluralization continued. College Composition and Communication, 57(4), 586-619.

Canagarajah, A. S., \& Wurr, A. J. (2011). Multilingual communication and language acquisition: New research directions. The Reading Matrix, 11(1), 1-15.

Consejo Académico de la Universidad de Antioquia. (2008, November). Acuerdo Académico 334. Medellin, CO. Universidad de Antioquia. Retrieved from http://www.udea.edu.co/ portal/page/portal/SedesDependencias/Idiomas/B.InformacionEscuela/F.Normativa/Ac uerdos?_piref471_121824627_471_121824255_121824255.tabstring=ConsejoAcademico.

Consejo Académico de la Universidad de Antioquia. (2012, March). Acuerdo Académico 407. Medellín, CO: Universidad de Antioquia. Retrieved from http://www.udea.edu.co/ portal/page/portal/SedesDependencias/Idiomas/B.InformacionEscuela/F.Normativa/Ac uerdos?_piref471_121824627_471_121824255_121824255.tabstring=ConsejoAcademico.

Council of Europe. (2001). Common European framework of reference for languages: Learning, teaching, assessment. Cambridge, UK: Cambridge University Press.

Espí, M. J., \& Azurmendi, M. J. (1996). Motivación, actitudes y aprendizaje del español como lengua extranjera [Motivation, attitudes and learning of Spanish as a foreign language]. RESLA, 11, 63-76.

Flowerdew, J., \& Peacock, M. (2001). Research perspectives on English for academic purposes. Cambridge, UK: Cambridge University Press. http://dx.doi.org/10.1017/CBO9781139524766.

Gardner, R. C. (1985). Social psychology and second language learning: The role of attitudes and motivation. London, UK: Arnold Publishers.

Ghani, M. (2003). Language learning strategies employed by L2 learners. Journal of Research (Faculty of Languages \& Islamic Studies), 4, 31-36.

Gremmo, M. J., \& Riley, P. (1995). Autonomy, self-direction and self-access in language teaching and learning: The history of an idea. System, 23(2), 151-164. http://dx.doi.org/ 10.1016/0346-251X(95)00002-2.

Hornberger, N. H. (2006). Frameworks and models in language policy and planning. In T. Ricento (Ed.), An introduction to language policy: Theory and method (pp. 24-41). Malden, MA: Blackwell Publishing.

Hughes, R. (2008). Internationalisation of higher education and language policy: Questions of quality and equity. Higher Education Management and Policy, 20(1), 111-128. http:// dx.doi.org/10.1787/hemp-v20-art6-en.

Hutchinson, T., \& Waters, A. (1987). English for specific purposes. Cambridge, UK: Cambridge University Press. http://dx.doi.org/10.1017/CBO9780511733031.

Keefe, J. W. (1991). Learning style: Cognitive and thinking skills. Reston, VA: National Association of Secondary School Principals. 
Kormos, J., \& Csizér, K. (2008). Age-related differences in the motivation of learning English as a foreign language: attitudes, selves, and motivated learning behavior. Language Learning, 58(2), 327-355. http://dx.doi.org/10.1111/j.1467-9922.2008.00443.x.

Krippendorff, K. (2004). Content analysis: An introduction to its methodology. London, UK: Sage Publications.

Lamb, M. (2004). Integrative motivation in a globalizing world. System, 32(1), 3-19. http://dx.doi.org/10.1016/j.system.2003.04.002.

Ministerio de Educación Nacional. (2006). Visión 2019 Educación: propuesta para discusión [Vision 2019 Education: Proposal for discussion]. Bogotá, CO: Author. Retrieved from http://www.mineducacion.gov.co/cvn/1665/articles-110603_archivo_pdf.pdf.

Ministerio de Educación Nacional. (2009). Internacionalización de la educación superior [Internalization of higher education] Retrieved from http://www.mineducacion.gov.co/ 1621/article-196472.html.

Ministerio de Educación Nacional. (2014). Programa Nacional de Inglés 2015-2025 [National English program 2015-2025]. Bogotá, CO: Author. Retrieved from http:// www.colombiaaprende.edu.co/html/micrositios/1752/articles-343287_recurso_1.pdf.

O’Malley, J. M., \& Chamot, A. U. (1990). Learning strategies in second language acquisition. Cambridge, UK: Cambridge University Press. http://dx.doi.org/10.1017/CBO9781139524490.

Phillipson, R. (2006). Language policy and linguistic imperialism. In T. Ricento (Ed.), An introduction to language policy: Theory and method (pp. 346-361). Malden, MA: Blackwell Publishing.

Richards, J. C., Platt, J., \& Platt, H. (1992). Dictionary of language teaching and applied linguistics (2nd ed.). London, UK: Longman.

Richterich, R. (1985). Besoins langagiers et objectifs d'apprentissage [Language needs and learning objectives]. Paris, FR: Hachette.

Rubin, J. (1987). Learner strategies: Theoretical assumptions, research history and typology. In A. L. Wenden \& J. Rubin (Eds.), Learner strategies in language learning (pp. 15-30). Englewood Cliffs, NJ: Prentice-Hall.

Ryan, R., \& Deci, E. (2000). Self-determination theory and the facilitation of intrinsic motivation, social development, and well-being. American Psychologist, 55(1), 68-78. http:/ /dx.doi.org/10.1037/0003-066X.55.1.68.

Schmidt, R., Boraie, D., \& Kassabgy, O. (1996). Foreign language motivation: Internal structure and external connections. In R. L. Oxford (Ed.), Language learning motivation: Pathways to the new century (pp. 9-70). Honolulu, HI: University of Hawaii Press.

Shim, S. R., \& Sim, T. S. (2011). EAP needs analysis in higher education: Significance and future direction. English for specific purposes world, 33(11), 1-11.

Shohamy, E. (2006). Language policy: Hidden agendas and new approaches. New York, NY: Routledge. bttp:/ / dx.doi.org/10.4324/9780203387962.

Siemens, G. (2006). Knowing knowledge. Retrieved from http://www.elearnspace.org/ KnowingKnowledge_LowRes.pdf.

Spolsky, B. (2004). Language policy. Cambridge, UK: Cambridge University Press. 
Tollefson, J. W. (2007). Ideology, language varieties, and ELT. In J. Cummis \& C. Davison (Eds.), International handbook of English language teaching (pp. 25-36). New York, NY: Springer Science \& Business Media. http://dx.doi.org/10.1007/978-0-387-46301-8_3.

Usma, J. (2009). Globalization and language and education reform in Colombia: A critical outlook. Íkala, Revista de Lenguaje y Cultura, 14(22) 19-42.

Wu, W.-C. V., Yen, L. L., \& Marek, M. (2011). Using online EFL interaction to increase confidence, motivation, and ability. Educational Technology \& Society, 14(3), 118-129.

\section{The Authors}

Paula Andrea Bedoya works as a teacher and researcher at Universidad de Antioquia (Colombia). She holds a Master's in Foreign Language Teaching and Learning from the same university.

Luz María Valencia holds a BA in Teaching Foreign Languages from Universidad de Antioquia (Colombia). Currently, she works as a teacher in the same university.

Juan Carlos Montoya holds a BA in Teaching Foreign Languages from Universidad de Antioquia (Colombia). Currently, he is a member of the research group GIAE and teaches in different programs of the School of Languages in the same university. 


\section{Appendix 1: Virtual Survey}

\section{Survey of professors enrolled in the program}

This survey aims at identifying the learning needs and interests of the professors enrolled in the EFL program.

The answers to this survey will be used only in this study and kept confidential. Please answer the following questions.

\section{Needs}

1. Why do you attend the program courses?
a. Postgraduate certification requirement
b. Professional development
c. Personal development
d. Preparation for international tests, scholarships, or university calls
e. Communication with international peers

2. You need English to:
a. Read academic tests
b. Participate in international events
c. Write research reports
d. Speak to international peers
e. Engage in informal conversations
f. Meet a contractual requirement

3. What language skills do you need to develop the most? (Lists of language skills)

\section{Interests, motivations, and likes:}

4. Which of the following topics would you like to study in class?
a. Culture
b. Topics specific to the profession
c. Everyday issues
d. Another?

5. What approach do you prefer?
a. $\quad$ English for academic purposes (to write research reports, to listen to lectures, etc.) 
b. English for specific purposes (related to your profession)

c. Conversational English (related to everyday issues)

6. Rank the following in-class activities according to preference $(1=$ not interesting, 2 = little interesting, 3 = interesting, 4 = very interesting)

_ Role plays

_ Debates

_ Games

_ Presentations

_ Grammar workshops

7. Which work dynamics facilitate your learning process most?

_ Individual work

_ Pair or small group work

_ Whole class work

_Another

8. Would you like to learn English in order to teach your own class in English?

\section{Study habits}

9. What do you do to study English?
a. Listen to music
b. Read news or other written texts
c. Solve doubts with English speakers
d. Practice English with advanced learners
e. Watch movies, TV, or videos
f. Visit web pages
g. Chat with friends (Skype, videocalls)
h. Practice with grammar and vocabulary worksheets.

10. How many hours of independent study do you invest in weekly? (Letters a-d list number of hours from one to five to study)

e. I have no spare time to study. 


\section{Lacks}

(Lacks explain the proficiency level and possible teaching and learning limitations to achieve learning objectives)

11. Rank the following ICT applications and devices according to how frequent you use them $(1=$ Never, $2=$ Occasionally, $3=$ Sometimes, $4=$ Frequently $)$

(List of electronic devices, web pages, and applications to rank)

12. What difficulties have you found in your learning process?

13. In the time you have been in the program, what technological, organizational, or administrative difficulties have you encountered? 


\section{Appendix 2: English Teachers' Interview}

1. Describe briefly your classes' organization, activities, resources, material, and assessment (ask for details regarding oral and written activities).

2. According to your experience in the program, what do you think professors need to learn?

3. To what extent do you consider that the course contents meet the learning needs you just mentioned?

4. According to your experience, what do you think professors want to learn?

5. To what extent do you consider that the course contents meet the learning needs you just mentioned?

6. Aiming at an improvement of the program, what does the program need to teach professors regarding their interests, lacks, and demands?

7. How do you promote independent learning among students? 


\section{Appendix 3: Coordinators' Interview}

1. What motivated you to coordinate the program? What were your goals as coordinator?

2. What limitations did you have for achieving those goals? What objective did you achieve?

3. What are the advantages and disadvantages of the program regarding academic and administrative aspects?

4. What requirements did the vice rector demand of the program when you were the coordinator? (e.g., coverage, professors' language proficiency, etc.)

5. What support did you receive from the Vice-Chancellor's office and the School of Languages at that moment?

6. According to your experience, which direction should the program take to meet external and university demands? 


\section{Appendix 4: Vice Rector's Interview}

1. Because there are no documents about the program, we would like to know when and why it was created.

2. What is the language policy the Vice Chancellor's office expects professors to achieve after completing the eight levels the program offers? Is there a language proficiency level these professors should achieve?

3. How does the academic and administrative support provided to the program contribute to the achievement of the expected language proficiency level?

4. Considering the increasing number of professors enrolled in the program in the last few years, what do you think the organizational and administrative constraints are to fulfilling program objectives?

5. What future expectations does the administration have for the program regarding academic, organizational, and administrative aspects?

6. Considering the university language demands an aspirant must meet and that many full time faculty positions are still vacant because aspirants cannot meet language requirements, we would like to know what the origin of this language requirement is. Is there a strategy to help professors to overcome this obstacle in the contractual process? 